\title{
CRÔNICA UNIVERSITÁRIA.
}

\section{Noé Azevedo, professor emérito.}

\section{A Redação.}

Reuniu-se a Congregação de professores em sessão solene, a 11 de agosto de 1971, sob a presidência do Magnífico Reitor da Universidade, professor Miguel Reale, para solenizar três fatos de capital importância para esta Faculdade: a outorga do título de professor emérito ao Dr. Noé Azevedo, o centésimo quadragésimo quarto aniversário da fundação dos cursos jurídicos no Brasil e a instalação dos cursos de Pós-Graduação.

Abrindo a sessão, S. Magnificência deu a palavra ao professor Basileu Garcia para saudar o homenageado, em nome da Congregação. $\mathrm{O}$ orador enalteceu a figura humana do eminente colega, seus atributos de autêntico advogado na batalha infatigável do Direito e de penalista de escol, precursor no Brasil da assistência tutelar.

Após a saudação, foi lida a ata da sessão da Congregação que concedeu o título de professor emérito ao Dr. Noé Azevedo, pelos relevantes serviços prestados à ciência jurídica e à docência. O senhor Diretor da Faculdade, professor Pinto Antunes, fez a entrega do diploma ao professor laureado, sob intensos aplausos da assembléia que se manteve de pé.

Com a palavra, o professor Noé desculpou-se por não ter escrito seu discurso, como o exigia aquela solenidade, sendo surpreendido com a leitura do emocionante trabalho elaborado com tanto carinho, e pronunciado com o calor envolvente da amizade pelo nobre colega.

Dirigiu seus agradecimentos aos componentes da mesa e às pessoas gradas presentes, acentuando os traços marcantes 
da atuação de cada um nos altos postos que ocupam. Referindo-se ao professor Basileu Garcia, observou que o mesmo viera para a Faculdade como professor consumado, grande sabedor da disciplina, que velara armas na brilhante carreira que fizera no Ministério Público da Capital.

Com a imensa bagagem de sólidos conhecimentos acumulados no exercício do árduo Ministério de promover a defesa da Sociedade, na Tribuna de Acusação, desde que subira à Cátedra passara a ensinar Direito Penal.

$\mathrm{E}$ assim preparado, transformou logo as suas preleções em acuradíssimo Compêndio de Direito Penal, enriquecendo a bibliografia da disciplina com preciosos livros e artigos da melhor doutrina.

Comprovando, mais uma vez, sua grande modéstia o professor Noé Azevedo fêz questão de dizer que durante os 37 anos e meio de professorado, mais não fizera do que estudar o mais humano de todos os ramos do Direito, sem ter conseguido fixar seus estudos sequer em um Curso de Direito Penal, constituindo sua produção jurídico-penal de ensino, especialmente de Criminologia e Estudos Penitenciários, voltados, mais para os temas do tratamento e recuperação dos delinquientes, do que para o diálogo do crime e da pena. Teve a preocupação de fazer os alunos gostarem da disciplina itespertando as atenções para as belezas e complexidades do código penal como uma forma de defesa e aprimoramento social, com menos dor, menos sofrimento, pois os delinqüentes são vítimas dos percalços da vida social, sendo contra a frase "luta pela vida" que deveria ser "cooperação" Referiu-se, ainda, à tecnologia como o quarto fator de produção que será a responsável pela evolução do mundo novo e seu reflexo no mundo jurídico. Terminando, disse que se afastara com o consolo de haver ensinado milhares de jovens a estudar Direito Penal e Ciências Afins, despertando nos mesmos o vivo interesse que centenas desses alunos têm demonstrado em trabalhos forenses, livros, monografias e artigos publicados. 
A seguir, o Magnífico Reitor fêz considerações sobre a importância dos cursos de Pós-Graduação e a necessidade da participação de professores e alunos nas duas fases do curso, mestrado e doutorado, que se constituem não apenas em conquista de títulos mas de tomada de posição na carreira universitária. Em seguida deu a palavra ao professor Philomeno Joaquim da Costa que discorreu sobre a data de fundação dos cursos jurídicos na Brasil e sobre o significado e objetivos dos cursos de Pós-Graduação, augurando que o centésimo quadragésimo quarto aniversário dos cursos jurídicos represente o "marco da fixação de uma autenticidade jurídica científica e que a Faculdade possa ostentar em seus portais o título: Escola de Altos Estudos Jurídicos."

Os discursos do professor Basileu Garcia e do professor Philomeno Joaquim da Costa são publicados na secção de Conferências e Discursos deste volume. 